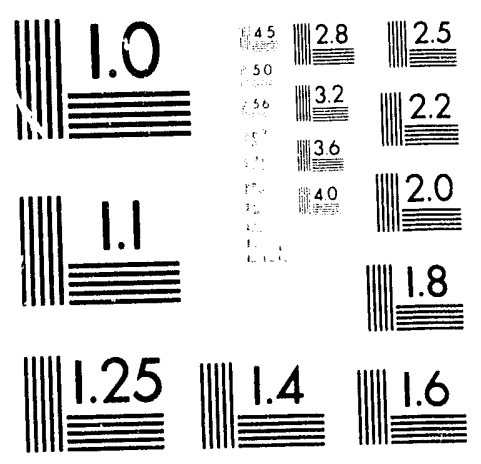



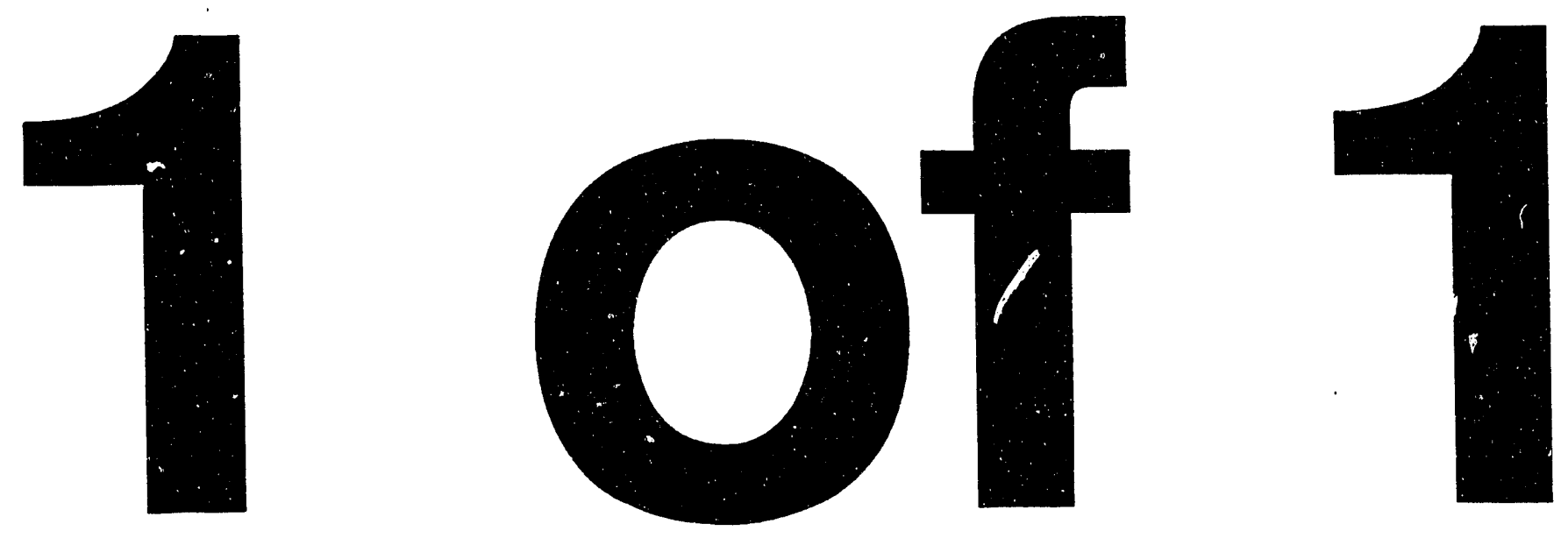
DERIVATION OF CESIUM-137 RESIDUAL RADIOACTIVE MATERIAL GUIDELINES FOR THE PEEK STREET SITE, SCHENECTADY, NEW YORK

\author{
by
}

L. Jones, M. Nimmagadda, and C. Yu

Environmental Assessmert and Information Sciences Division

January 1992

work supported by

U.S. Department of Energy 
Argonne National Laboratory

9700 South Cass Avenue, Argonne, Illinois 60439

\title{
DERIVATION OF CESIUM-137 RESIDUAL RADIOAC'TIVE MATERIAL GUIDELINES FOR THE PEEK STREET SITE, SCHENECTADY, NEW YORK
}

\author{
by
}

L. eTones, M. Nimmagadda, and C. Yu

Environmental Assessment and Information Sciences Division

January 1992

work supported by

U.S. Department of Energy

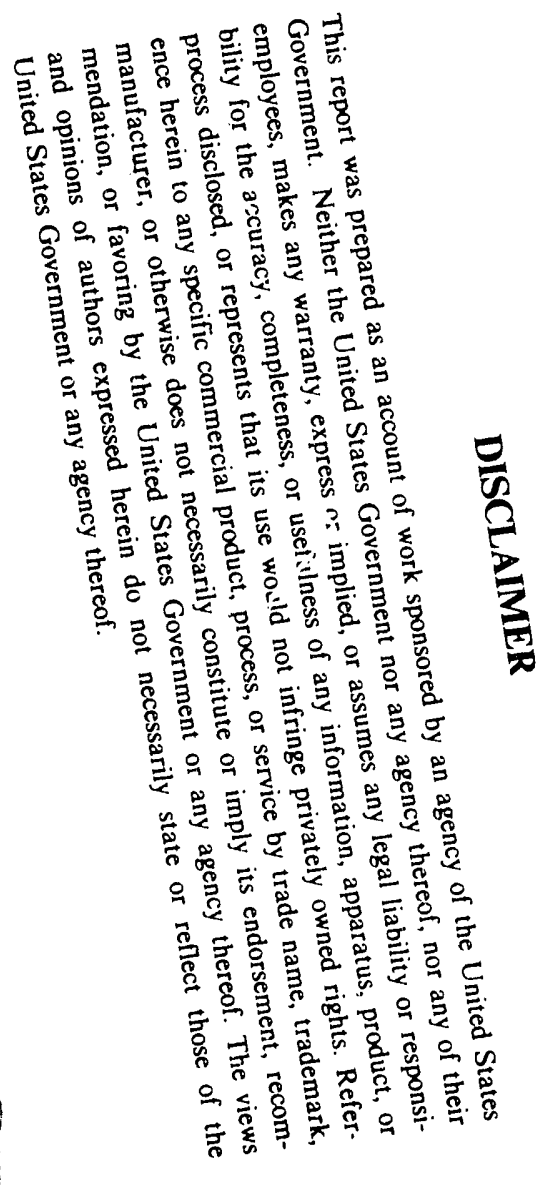




\section{CONTENTS}

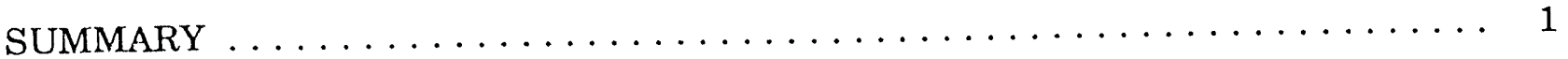

1 INTRODUCTION AND BRIEF HISTORY $\ldots \ldots \ldots \ldots \ldots \ldots \ldots \ldots \ldots \ldots \ldots$

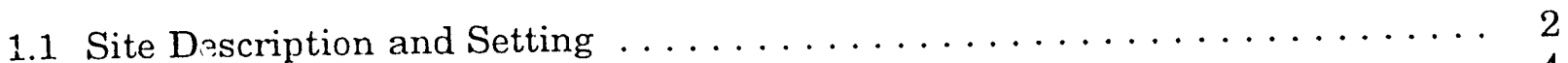

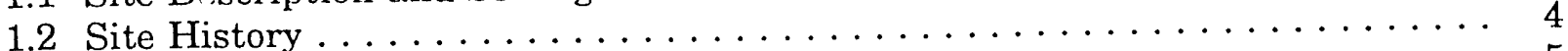

1.3 Derivation of Cleanup Guidelines $\ldots \ldots \ldots \ldots \ldots \ldots \ldots \ldots \ldots \ldots \ldots \ldots \ldots$

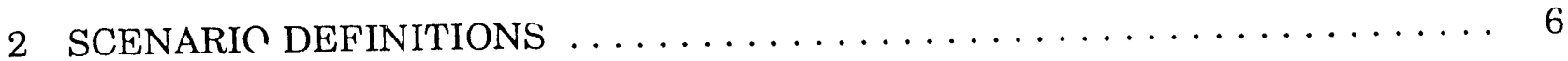

3 DOSE/SOURCE CONCENTRATION RATIOS $\ldots \ldots \ldots \ldots \ldots \ldots \ldots \ldots \ldots$

4 REIDUAL RADIOACTIVE MATERIAL GUIDELINES $\ldots \ldots \ldots \ldots \ldots \ldots$

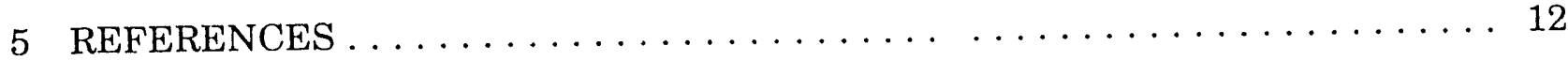

APPENDIX: Parameters Used in the Analysis of the Peek Street Site . . . . . . . 15

\section{FIGURES}

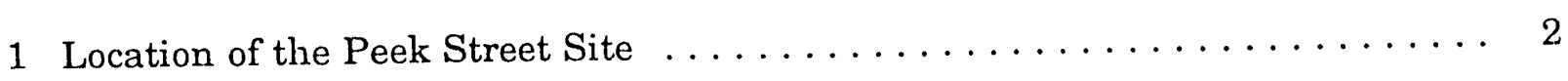

2 Map of the Peek Street Site $\ldots \ldots \ldots \ldots \ldots \ldots \ldots \ldots \ldots \ldots$

\section{TABLES}

1 Summary of Pathways for Scenarios A, B, and C at the Peek Street Site .... 7

2 Maximum Dose/Source Concentration Ratios for Scenarios A, B, and C at the Peek Street Site . . . . . . . . . . . . . . . . . . . 10

3 Total Dose/Source Concentration Ratios for Cesium-137 at the Peek Street Site

4 Residual Radioactive Material Guidelines for Cesium-137 at the Peek Street Site . . . . . . . . . . . . . . . . . . . . 12

5 Ranges for Hot Spot Multiplication Factors $\ldots \ldots \ldots \ldots \ldots \ldots \ldots \ldots$

A.1 Parameters Used in the RESRAD Code for the Analysis of the Peek Street Site 


\section{DERIVATION OF CESIUM-137 RESIDUAL RADIOACTIVE MATERIAL GUIDELINES FOR THE PEEK STREET SITE, SCHENECTADY, NEW YORK}

by

L. Jones, M. Nimmagadda, and C. Yu

\section{SUMMARY}

Residual radioactive material guidelines for cesium-137 were derived for the Peek Street site in Schenectady, New York. The derivation was based on the requirement that the 50-year committed effertive dose equivalent to a hypotheíical individual who lives or works in the immediate vicinity of the Peek Street site should not exceed a dose of $100 \mathrm{mrem} / \mathrm{yr}$ following remedial action.

The U.S. Department of Energy (DOE) residual radioactive material guideline computer code, RESRAD, which implements the methodology described in the DOE manual for implementing residual radioactive material guidelines, was used in this evaluation. Three potential scenarios were considered for the site on the assumption that for a period of 1,000 years following remedial action, the site will be " tilized without radiological restrictions. The scenarios vary with regard to use of the site, time spent at the site, and sources of food consumed. The results of the evaluation indicate that the basic dose limit of $100 \mathrm{mrem} / \mathrm{yr}$ will not be exceeded for cesium-137 within 1,000 years, provided that the soll concentration of cesium-137 at the Peek Street site does not exceed the following levels: $98 \mathrm{pCi} / r$ for Scenario A (industrial worker: the expected scenario), $240 \mathrm{pCi} / \mathrm{g}$ for Scenario B (recreationist: a plausible scenario), and $34 \mathrm{pCi} / \mathrm{g}$ for Scenario $\mathrm{C}$ (resident farmer ingesting food produced in the decontaminated area: a plausible scenario).

The derived guidelines are linearly proportional to the dose limit used in the calculations. In setting the actual cesium-137 guidelines for the Peek Street site, DOE will apply the as-low-as-reasonably-achievable (ALARA) policy to the decision-making process, along with other factors, such as whether a particular scenario is reasonable and appropriate.

\section{INTRODUCTION AND BRIEF HISTORY}

The Peek Street Industrial Facility is located at 425 Peek Street, Schenectady, New York (Figure 1). A variety of operations using radioactive materials were conducted at the site between 1947 and 1955. It is the policy of the U.S. Department of Energy (DOE) to verify that conditions at such sites or facilities comply with current federal guidelines. In 


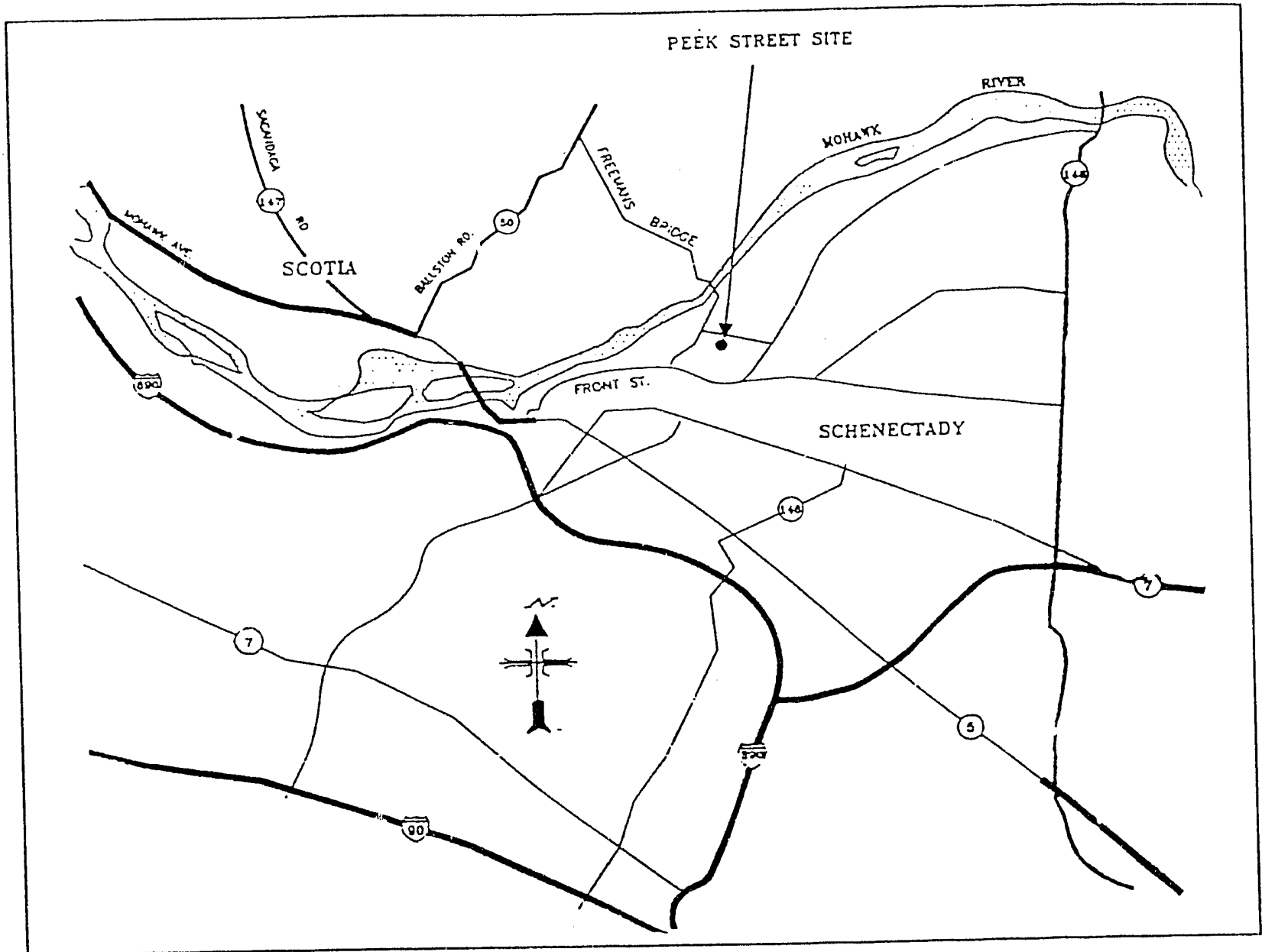

FIGURE 1 Location of the Peek Street Site (Source: Foley et al. 1992)

November 1989, a radiological survey was conducted by Oak Ridge National Laboratory (ORNL) at the request of the Office of Naval Reactors through the Office of Remedial Action and Waste Technology.

The RESRAD computer code (Gilbert et al. 1989), which implements the guidance of DOE Order 5400.5 (DOE 1990), is used to derive residual radionuclide guidelines on a sitespecific basis. This report presents the cesium-137 guidelines derived for the Peek Street site on the basis of a dose limit of $100 \mathrm{mrem} / \mathrm{yr}$.

\subsection{SITE DESCRIPTION AND SETTING}

The Peek Street site is located in Schenectady, New York, about $27 \mathrm{~km}$ (17 mi) northwest of Albany, New York (Figure 1). The site comprises approximately $18,200 \mathrm{~m}^{2}$ ( 4.5 acres). The site is bounded on the southeast by a city-owned bike path and on the southwest by Peek Street (Figure 2). The Delaware and Hudson Railroad runs roughly along the northern edge of the site. 


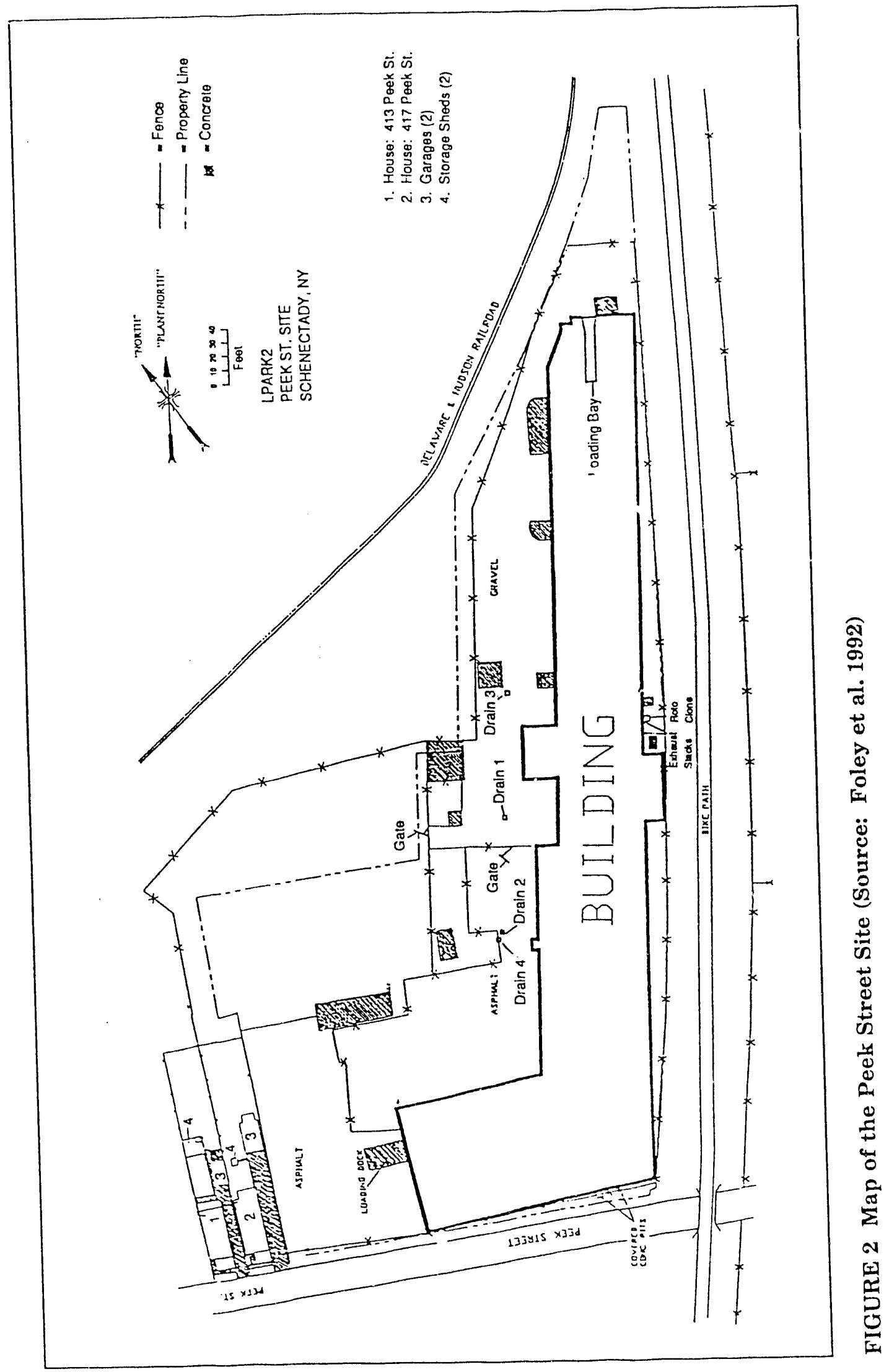


A large L-shaped factory building occupies much of the Peek Street site property; asphalt and gravel cover most of the area surrounding the building. Adjoining the southwest side of the Peek Street property are two residential vicinity properties located at 413 and 417 Peek Street.

\subsection{SITE HISTORY}

The Peek Street Industrial Facility was operated by the General Electric Company for the Atomic Energy Commission (AEC) between 1947 and 1955. Radioactive materials were used in a variety of operations conducted at the site; primary activities included the design of an intermediate breeder reactor and the development of a chemical process for the recovery of uranium and plutonium from spent reactor fuel. Nonradioactive beryllium metal was machined on the site for breeder reactor application. The site was decommissioned and released in October 1955.

At the request of the Office of Naval Reactors through the Office of Remedial Action and Waste Technology, a site visit and preliminary scoping survey of the Peek Street facility were conducted by ORNL in July 1988. In November 1988, the major portion of the cityowned bike path underwent a preliminary survey. Small amounts of residual radioactivity derived from former operations were identified in only two localized spots outdoors; indoors, only a crack in the old vault area was discovered. A comprehensive survey was then performed between August and November 1989 to definitively characterize current radiological conditions at the site. Included in this second survey were a small, formerly inaccessible portion of the city-owned property; the two vicinity properties southwest of the facility; the commercially-owned property to the north of the site; and the industrial property. The results of the comprehensive second survey led to an additional sampling trip in June 1990.

Cesium-137 was found at concentrations of 0.009 to $16 \mathrm{pCi} / \mathrm{g}$ at the surface and 0.02 to $1.1 \mathrm{pCi} / \mathrm{g}$ in subsurface samples at the industrial property of the Peek Street site. Generally, the cesium-137 concentrations were $1.0 \mathrm{pCi} / \mathrm{g}$ or less. The higher values were found in samples taken from areas where rainwater would be expected to collect. The highest concentration of cesium-137 (16 pCi/g) was found in a sample taken in a low-lying area beneath the drip line of the building. Concentrations at the city-owned property ranged from 0.02 to $1.2 \mathrm{pCi} / \mathrm{g}$. A similar range $(0.01$ to $1.9 \mathrm{pCi} / \mathrm{g}$ ) was measured at the commerciallyowner: railroad property. The cesium-137 concentrations at the vicinity properties fell within the range of 0.13 tn $0.84 \mathrm{pCi} / \mathrm{g}$ (Foley et al. 1992).

Average background soil concentration levels of cesium-137 were found to range from 0.76 to $1.2 \mathrm{pCi} / \mathrm{g}$ in Schenectady and nearby Glenville, New York. The cesium-137 concentrations measured at the Peek Street site generally fall within this background concentration range. All measured concentration levels of cesium-137 at the Peek Street site lie below the $80 \mathrm{pCi} / \mathrm{g}$ limit previously applied by DOE to Formerly Utilized Sites Remedial Action Program (FUSRAP) sites (Foley et al. 1992). 


\subsection{DERIVATION OF CLEANUP GUIDELINES}

Although most DOE cleanup guidelines applicable to remedial actions at FUSRAP sites are generic in nature (DOE 1990), guidelines for cesium are derived on a site-specific basis. The purpose of this report is to present the derivation of the residual radioactive material guidelines for cesium-137 that are applicable to remedial action at the Peek Street site; that is, the residual concentration of cesium-137 in a homogeneously contaminated area that must not be exceeded if the site is to be released for use without radiological restrictions. The derivation of site-specific cesium-137 guidelines for the Peek Street site is based on a dose limit of $100 \mathrm{mrem} / \mathrm{yr}$ (DOE 1990), assuming that cesium-137 is the only radionuclide present at an above-background concentration. The RESRAD computer code, which implements the methodology described in the DOE manual for implementing residual radioactive material guidelines (Gilbert et al. 1989), was used to derive these guidelines. 


\section{SCENARIO DEFINITIONS}

Three potential exposure scenarios were considered for the Peek Street site. In all scenarios, it is assumed that, at some time within 1,000 years, the site will be released for use without radiological restrictions following $r$ medial action.

Scenario A (the expected scenario) assumes industrial use of the site. Under this scenario, a hypothetical individual is assumed to work in the area of the site for 8 hours per day ( 6 hours outdocrs and 2 hours indoors), 5 days per week, 50 weeks per year. Therefore, in one year the industrial worker is assumed to spend $17 \%$ of the time working outdoors at the site, $6 \%$ working indoors at the site, and $77 \%$ away from the site. It is assumed that the worker does not ingest water, plant foods, or fish obtained from the decontaminated area, or meat or milk from livestock raised in the decintaminated area.

Scenario B (a plausible scenario) assumes recreational use of the site. It is assumed that at some time in the future, the whole site will be transformed into a public recreational park. Under this scenario, a hypothetical individual spends 15 hours per week, 50 weeks per year in the decontaminated area of the park. Therefore, in one year this generic recreationist spends $9 \%$ of the time in the decontaminated area and $91 \%$ of the time away from the site. It is assumed that the recreationist does not ingest water or plant foods obtained from the decontaminated area, or meat or milk from livestock raised in the decontaminated area. Also, it is assumed that no fish or other aquatic food consumed by the recreationist is obtained from nearby rivers.

Scenario C (a plausible scenario) assumes that the site is used as a farm and that at some time in the future, the entire site will be transformed into a farm. Under this scenario, in one year a hypothetical resident farmer is assumed to spend $50 \%$ of the time indoors in the decontaminated area, $25 \%$ outdoors in the decontaminated area, and $25 \%$ away from the site.

The resi jent farmer is assumed to ingest plant foods grown in thc garden and fish and other aquatic food obtained totally from nearby rivers. The individual also ingests meat and milk from livestock raised in the decontaminated area.

Potential radiation doses resulting from the following eight exposure pathways are analyzed:

- Direct exposure to external radiation from the decontaminated soil material,

- Internal radiation from inhalation of contaminated dust,

- Internal radiation from ingestion of plant foods grown in the decontaminated area and irrigated with water from local groundwater wells, 
- Internal radiation from ingestion of meat from livestock fed with fodder grown in the decontaminated area and with water drawn from inside the area,

- Internal radiation from ingestion of milk from livestock fed with fodder grown in the decontaminated area and with water drawn from inside the area,

- Internal radiation from ingestion of water drawn from inside the area,

- Internal radiation from ingestion of fish and other aquatic food from nearby rivers, and

- Internal radiation from the ingestion of on-site soil.

All pathways considered for scenarios A, B, and C are summarized in Table 1.

The RESRAD computer code (Gilbert et al. 1989) was used to calculate the potential radiation doses to the hypothetical future industrial worker, recreationist, or resident farmer, on the basis of the following assumptions:

- During one year, the industrial worker spends 1,500 hours (17\%) outdoors at the site, 500 hours $(6 \%)$ indoors at the site, and 6,760 hours $(77 \%)$ away from the decontaminated area. The recreationist spends 750 hours (9\%) per year on-site. The resident farmer spends 4,380 hours $(50 \%)$ indoors, 2,190 hours $(25 \%)$ outdoors in the decontaminated area, and 2,190 hours (25\%) away from the site.

TABLE 1 Summary of Pathways for Scenarios A, B, and C at the Peek Street Site ${ }^{\mathrm{a}}$

\begin{tabular}{|c|c|c|c|}
\hline Pathway & $\begin{array}{c}\text { Scenario } \\
\text { A }\end{array}$ & $\begin{array}{c}\text { Scenario } \\
\text { B }\end{array}$ & $\begin{array}{c}\text { Scenario } \\
\mathrm{C} \\
\end{array}$ \\
\hline External exposure & Yes & Yes & Yes \\
\hline Inhalation & Yes & Yes & Yes \\
\hline Radon & No & No & No \\
\hline Ingestion of plant foods & No & No & Yes \\
\hline Ingestion of meat & No & No & Yes \\
\hline Ingestion of milk & No & $N_{0}$ & Yes \\
\hline Ingestion of fish & No & No & Yes \\
\hline Ingestion of soil & Yes & Yes & Yes \\
\hline Ingestion of water & No & No & Yes \\
\hline
\end{tabular}

a Scenario A, industrial worker; Scenario B, recreationist; Scenario C, resident farmer. 
- The walls, floors, and foundation of the house or office building reduce external exposure by $30 \%$; the indour dust level is $40 \%$ of the outdoor dust level (Gilbert et al. 1989).

- The size of the decontaminated area is large enough that $50 \%$ of the plant food diet consumed by the resident farmer is grown in a garcien in the decontaminated area. The industrial worker or the recreationist does not consume these plant foods.

- The size of the decontaminated area is large enough to provide sufficient meat and milk for the resident farmer from livestock raised (i.e., foraged) in the decontaminated area. The industrial worker or the recreationist does not consume this meat or milk.

- All the fish and other aquatic food consumed by the farmer are obtained totally from nearby rivers. The industrial worker or the recreationist does not consume aquatic food obtained from the site.

- After remedial action, no cover material is placed over the decontaminated area.

- The thickness of the contaminated zone is a conservative average value used in deriving residual radioactive guidelines for uranium (Yu 1989). The whole area of the Peek Street site $\left(18,200 \mathrm{~m}^{2}\right.$ [4.5 acres]) was conservatively assumed to be homogeneously contaminated with an average thickness of $0.3 \mathrm{~m}(1 \mathrm{ft})$. 


\section{DOSE/SOURCE CONCENTRATION RATIOS}

The RESRAD computer cocic (Gilbert et al. 1989) was used to calculate the dose/source concentration ratio $\operatorname{DSR}_{\mathrm{p}}(\mathrm{t})$ to: cesium-137 at pathway $p$ and time $t$ after remedial action. The time frame considered in this analysis was 1,000 years. Radioactive decay and ingrowth were considered in deriving the dose/source concentration ratios. The various parameters used in the RESRAD code for this analysis are listed in the Appendix. The calculated maximum dose/source concentration ratios for all pathways are presented in Table 2 for scenarios A, B, and C. For each scenario, the maximum dose/source concentration ratios would occur at time zero (immediately after remedial action). The primary pathway for scenarios $\mathrm{A}, \mathrm{L}$, and $\mathrm{C}$ would be external exposure to gamma radiation.

The summation of $\operatorname{DSR}_{i p}(t)$ for all pathways $p$ is the $\operatorname{DSR}_{i}(t)$ for the $i$ th isotope, that is,

$$
D S R_{i}(t)=\sum_{p} D S R_{i p}(t)
$$

The total dose/source concentration ratio for cesium 137 can be calculated as

$$
D S R_{C s-137}(t)=\sum_{p} D S R_{C s-137_{2} p}(t)
$$

where $\operatorname{DSR}_{\mathrm{Cs}-137, \mathrm{p}}(\mathrm{t})$ is the dose/source concentration ratio for pathway $\mathrm{p}$.

The total dose/source concentration ratios for cesium-137 are provided in Table 3. These ratios were used to determine the allowable residual radioactivity for cesium-137 at, the Peek Street site. 
TABLE 2 Maximum Dose/Source Concentration Ratios for Scenarios $A, B$, and $C$ at the Peek Street Site

\begin{tabular}{lccc} 
& \multicolumn{3}{c}{ Maximum $\begin{array}{c}\text { Dose/Source Concentration Ratio } \\
(\mathrm{mrem} / \mathrm{yr}) /(\mathrm{pCi} / \mathrm{g})^{\mathrm{a}}\end{array}$} \\
\cline { 2 - 4 } \multicolumn{1}{c}{ Pathway } & Scenario A & Scenario B & Scenario C \\
\hline External exposure & 1.0 & $4.2 \times 10^{-1}$ & 2.9 \\
Inhalat:on & $1.0 \times 10^{-5}$ & $4.5 \times 10^{-6}$ & $2.4 \times 10^{-5}$ \\
Radon & 0 & 0 & 0 \\
Ingestion of plant foods & 0 & 0 & $2.9 \times 10^{-3}$ \\
Ingestion of meat & 0 & 0 & $3.6 \times 10^{-3}$ \\
Ingestion of milk & 0 & 0 & $7.1 \times 10^{-4}$ \\
Ingestion of fish & 0 & 0 & 0 \\
Ingestion of soil & $4.2 \times 10^{-4}$ & $1.6 \times 10^{-4}$ & $1.4 \times 10^{-3}$ \\
Ingestion of water & 0 & 0 & 0 \\
\hline
\end{tabular}

a Maximum dose/source concentration ratios would occur at time zero (immediately following remedial action); all values are reported to two significant figures.

TABLE 3 Total Dose/Source Concentration Ratios for Cesium-137 at the Peek Street Site ${ }^{a}$

\begin{tabular}{cc}
\hline & $\begin{array}{c}\text { Total Dose Source } \\
\text { Concentration Ratio } \\
(\mathrm{mrem} / \mathrm{yr} / \mathrm{pCi} / \mathrm{g})^{\mathrm{a}}\end{array}$ \\
\hline Scenario & 1.0 \\
B & $4.2 \times 10^{-13}$ \\
C & 2.9 \\
\hline
\end{tabular}

a Scenario A, industrial worker; Scenario B, recreationist; Scenario C, resident farmer.

b All values are reported to two significant figures. 


\section{RESIDUAL RADIOACTIVE MATERIAL GUIDELINES}

The residual radioactive material guideline is the concentration of residual radioactive material that can remain in a decontaminated area and still allow use of the area without radiological restrictions. Given the DOE annual radiation dose limit of $100 \mathrm{mrem} / \mathrm{yr}$ for an individual (DOE 1990), the residual radioactive material guideline $G$ for cesium-137 at the Peek Street site can be calculated as

$$
\mathrm{G}=100 / \mathrm{DSR}
$$

where DSR is the total dose/source concentration ratio listed in Table 3 . The calculated residual radioactive materia' guidelines for cesium-137 are presented in Table 4.

The derived guidelines for cesium-137 would be 98,240 , and $34 \mathrm{pCi} / \mathrm{g}$ for scenarios $\mathrm{A}, \mathrm{B}$, and $\mathrm{C}$, respectively. The derived guidelines are linearly proportional to the dose limit used in the calculation.

When implementing the derived radionuclide guidelines for decontamination of a site, the law of sum of fractions applies. That is, the summation of the fractions of radionuclide concentrations $S_{i}$ remaining on-site, averaged over an area of $100 \mathrm{~m}^{2}\left(120 \mathrm{yd}^{2}\right)$ and a depth of $15 \mathrm{~cm}$ ( 6 in.) and divided by their guidelines $\mathrm{G}_{\mathrm{i}}$, should not be greater than unity, that is,

$$
\sum_{i} S_{i} / G_{i} \leq 1
$$

The derived guidelines listed in Table 4 are for a large, homogeneously contaminated area. For a small, isolated area of contamination, the allowable concentration that can remain on-site may be higher than the homogeneous guideline, depending on the size of the area of contamination, and in accordance with Table 5. 
TABLE 4 Residual Radioactive

Material Guidelines for

Cesium-137 at the

Peek Street Site ${ }^{\mathrm{a}}$

\begin{tabular}{cc}
\hline Scenario & $\begin{array}{c}\text { Guideline } \\
(\mathrm{pCi} / \mathrm{g})^{\mathrm{b}}\end{array}$ \\
\hline $\mathrm{A}$ & 98 \\
$\mathrm{~B}$ & 240 \\
$\mathrm{C}$ & 34 \\
\hline
\end{tabular}

a Scenario A, industrial worker; Scenario B, recreationist;

Scenario C, resident farmer.

b Ali values are reported to two significant figures.

TABLE 5 Ranges for Hot Spot Multiplication Factors

\begin{tabular}{cc}
\hline Range & $\begin{array}{c}\text { Factor } \\
\text { (multiple of } \\
\text { authorized limit) }\end{array}$ \\
\hline$<1 \mathrm{~m}^{2}$ & $10^{\mathrm{a}}$ \\
$1-<3 \mathrm{~m}^{2}$ & 6 \\
$3-<10 \mathrm{~m}^{2}$ & 3 \\
$10-25 \mathrm{~m}^{2}$ & 2 \\
\hline
\end{tabular}

a Areas less than $1 \mathrm{~ns}^{2}$ are to be averaged over a $1-\mathrm{m}^{2}$ area, and that average shall not exceed 10 times the authorized limit. 


\section{REFERENCES}

Foley, R.D., et al., 1992, Radiological Survey Results for the Peek Street Site Properties, Schenectady, New York, ORNL-6623, prepared by Oak Ridge National Laboratory for U.S. Department of Energy, Sept.

Gilbert, T.L., et al., 1989, A Manual for Implementing Residual Radioactive Material Guidelines, ANL/ES-160, DOE/CH/8901, prepared by Argonne National Laboratory for U.S. Department of Energy, June.

U.S. Department of Energy (DOE), 1990, Radiation Protection of the Public and Environment, DOE Order 5400.5, Feb.

Yu, C., 1989, Uranium Guidelines for the Peek Street Site, Schenectady, New York, Argonne National Laboratory, Sept. 


\section{APPENDIX: \\ PARAMETERS USED IN THE ANALYSIS OF THE PEEK STREET SITE}

The parametric values used in the RESRAD code for the analysis of the Peek Street site are listed in Table A.1. All parametric values are reported to three significant figures. Some
parametric values are specific to the Peek Street site; others are generic.

TABLE A.1. Parameters Used in the RESRAD Code for the Analysis of the Peek Street Site

\begin{tabular}{|c|c|c|c|c|}
\hline \multirow[b]{2}{*}{ Parameter } & \multicolumn{4}{|c|}{ Value } \\
\hline & Unit & Scenario A & Scenario B & Scenario $\mathbf{C}$ \\
\hline Area of contaminated zone ${ }^{\mathrm{a}}$ & $\mathrm{m}^{2}$ & 18,200 & 18,200 & 18,200 \\
\hline Thickness of contaminated zone ${ }^{\mathrm{a}}$ & m & 0.3 & 0.3 & 0.3 \\
\hline Length parallel to aquifer flow & $\mathrm{m}$ & not used & not used & 135 \\
\hline Cover depth ${ }^{\mathrm{a}}$ & m & 0 & 0 & 0 \\
\hline Density of contaminated zone $\mathrm{e}^{\mathrm{a}}$ & $\mathrm{g} / \mathrm{cm}^{3}$ & 1.6 & 1.16 & 1.16 \\
\hline Contaminated zone erosion rate ${ }^{\mathrm{a}}$ & $\mathrm{m} / \mathrm{yr}$ & 0 & 0 & 0 \\
\hline Contaminated zone total porosity & $\cdot$ & 0.48 & 0.48 & 0.48 \\
\hline Contaminated zone effective porosity & - & 0.24 & 0.24 & 0.24 \\
\hline Contaminated zone hydraulic conductivity & $\mathrm{m} / \mathrm{yr}$ & 3.2 & 3.2 & 3.2 \\
\hline Contaminated zone b parameter ${ }^{b}$ & - & 5.3 & 5.3 & 5.3 \\
\hline Evapotranspiration coefficient ${ }^{\mathrm{a}}$ & $\cdot$ & 0.85 & 0.85 & 0.85 \\
\hline Precipitation $^{\mathrm{a}}$ & $\mathrm{m} / \mathrm{yr}$ & 0.89 & 0.89 & 0.89 \\
\hline Irrigation ${ }^{b}$ & $\mathrm{~m} / \mathrm{yr}$ & not used & not used & 0.2 \\
\hline Irrigation mode ${ }^{b}$ & $\cdot$ & overhead & overhead & overhead \\
\hline Runoff coefficient ${ }^{b}$ & - & 0.2 & 0.2 & 0.2 \\
\hline Watershed area for nearby pond ${ }^{b}$ & $\mathrm{~m}^{2}$ & not used & not used & $1,000,000$ \\
\hline Density of saturated zone $\mathrm{e}^{\mathrm{a}}$ & $\mathrm{g} / \mathrm{cm}^{3}$ & not used & not used & 1.16 \\
\hline Gaturated zone total porosity ${ }^{\mathrm{a}}$ & - & not used & not used & 0.48 \\
\hline Saturated zone effective porosity & - & not used & not used & 0.24 \\
\hline Saturated zone hydraulic conductivity & $\mathrm{m} / \mathrm{yr}$ & not used & not used & 100 \\
\hline Saturated zone hydraulic gradient ${ }^{\mathrm{b}}$ & $\cdot$ & not used & not used & 0.02 \\
\hline
\end{tabular}


TABLE A.1 (Cont'd)

\begin{tabular}{|c|c|c|c|c|}
\hline \multirow[b]{2}{*}{ Parameter } & \multicolumn{4}{|c|}{ Value } \\
\hline & Unit & Scenario A & Scenario B & Scenario C \\
\hline Saturated zone b parameter ${ }^{b}$ & - & not used & not used & 5.3 \\
\hline Water table drop rate & $\mathrm{m} / \mathrm{yr}$ & not used & not used & 0 \\
\hline Well pump intake depth (below water table) ${ }^{b}$ & $\mathrm{~m}$ & not used & not used & 10.0 \\
\hline Model: nondispersion (ND) or mass-balance $(\mathrm{MB})^{\mathrm{b}}$ & - & not used & not used & ND \\
\hline Number of unsaturated zone strata & - & not used & not used & 1 \\
\hline Unsaturated zone 1 , thickness ${ }^{\mathrm{a}}$ & $\mathrm{m}$ & not used & not used & 5.7 \\
\hline Unsaturated zone 1 , soil density & $\mathrm{g} / \mathrm{cm}^{3}$ & not used & not used & 1.16 \\
\hline Unsaturated zone 1 , total porosity ${ }^{\mathrm{a}}$ & - & not used & not used & 0.48 \\
\hline Unsaturated zone 1 , soil-specific b parameter ${ }^{b}$ & - & not used & not used & 5.3 \\
\hline Unsaturated zone 1 , hydraulic conductivity & $\mathrm{m} / \mathrm{yr}$ & not used & not used & 3.2 \\
\hline \multicolumn{5}{|l|}{ Distribution coefficient $t^{b}$} \\
\hline Contaminated zone & & 1,000 & 1,000 & 1,000 \\
\hline Saturated zone & & 1,000 & 1,000 & 1,000 \\
\hline Unsaturated zone & & 1,000 & 1,000 & 1,000 \\
\hline Inhalation rate ${ }^{b}$ & $\mathrm{~m}^{3} / \mathrm{yr}$ & 8,400 & 8,400 & 8,400 \\
\hline Mass loading for inhalation ${ }^{b}$ & $\mathrm{~g} / \mathrm{m}^{3}$ & 0.0002 & 0.0002 & 0.0002 \\
\hline Occupancy and shielding factor, external gamma & - & 0.21 & 0.086 & 0.6 \\
\hline Occupancy factor, inhalation ${ }^{\mathrm{a}}$ & - & 0.19 & 0.086 & 0.45 \\
\hline Shape factor, external gamma ${ }^{b}$ & - & 1 & 1 & 1 \\
\hline Dilution length for airborne dust, inhalation ${ }^{b}$ & $\mathrm{~m}$ & 3 & 3 & 3 \\
\hline Fruit, vegetable, and grain consumption ${ }^{b}$ & $\mathrm{~kg} / \mathrm{yr}$ & not used & not used & 160.0 \\
\hline Leafy vegetable consumption ${ }^{b}$ & $\mathrm{~kg} / \mathrm{yr}$ & not used & not used & 14.0 \\
\hline Milk consumption ${ }^{b}$ & L/yr & not used & not used & 92.0 \\
\hline Meat and poultry consumption ${ }^{b}$ & $\mathrm{~kg} / \mathrm{yr}$ & not used & not used & 63 \\
\hline Fish consumption ${ }^{\mathrm{b}}$ & $\mathrm{kg} / \mathrm{yr}$ & not used & not used & 5.4 \\
\hline Other seafood consumption ${ }^{b}$ & $\mathrm{~kg} / \mathrm{yr}$ & not used & not used & 0.9 \\
\hline Soil ingestion ${ }^{b}$ & $\mathrm{~kg} / \mathrm{yr}$ & 36.5 & 36.5 & 36.5 \\
\hline Drinking water intake ${ }^{b}$ & $\mathrm{~L} / \mathrm{yr}$ & not used & not used & 410. \\
\hline Fraction of drinking water from site & $\cdot$ & not used & not used & 1.0 \\
\hline Fraction of aquatic food from site ${ }^{a}$ & $\cdot$ & not used & not used & 1.0 \\
\hline
\end{tabular}


TABLE A.1 (Cont'd)

\begin{tabular}{|c|c|c|c|c|}
\hline \multirow[b]{2}{*}{ Parameter } & \multicolumn{4}{|c|}{ Value } \\
\hline & Unit & Scenario A & Scenario B & Scenario C \\
\hline Livestock fodder intake for meat ${ }^{b}$ & $\mathrm{~kg} / \mathrm{d}$ & not used & not used & 68.0 \\
\hline Livestock fodder intake for milk ${ }^{b}$ & $\mathrm{~kg} / \mathrm{d}$ & not used & not used & 55.0 \\
\hline Livestock water intake for meat ${ }^{b}$ & $\mathrm{~L} / \mathrm{d}$ & not used & not used & 50.0 \\
\hline Livestock water intake for milk ${ }^{b}$ & $\mathrm{~L} / \mathrm{d}$ & not used & not used & 160.0 \\
\hline Mass loading for foliar deposition ${ }^{b}$ & $\mathrm{~g} / \mathrm{m}^{3}$ & not used & not used & 0.0001 \\
\hline Depth of soil mixing layer ${ }^{b}$ & $\mathrm{~m}$ & 0.15 & 0.15 & 0.15 \\
\hline Depth of roots ${ }^{b}$ & $\mathrm{~m}$ & not used & not used & 0.9 \\
\hline \multicolumn{5}{|l|}{$\begin{array}{l}\text { Ground water fractional usage } \\
\text { (balance from surface water): }\end{array}$} \\
\hline Drinking water ${ }^{\mathrm{a}}$ & & not used & not used & 1.0 \\
\hline Livestock water" & & not used & not used & 1.0 \\
\hline Irrigation $^{\mathrm{a}}$ & & not used & not used & 1.0 \\
\hline Total porosity of the cover material ${ }^{a}$ & - & not used & not used & not used \\
\hline Total porosity of the house or building foundation ${ }^{b}$ & - & not used & not used & not used \\
\hline $\begin{array}{l}\text { Volumetric water content of the cover } \\
\text { material }^{b}\end{array}$ & - & not used & not used & not used \\
\hline Volumetric water content of the foundation ${ }^{b}$ & - & not used & not used & not used \\
\hline Diffusion coefficient for radon gas: & $\mathrm{m}^{2} / \mathrm{s}$ & & & \\
\hline in cover material ${ }^{b}$ & & not used & not used & not used \\
\hline in foundation material ${ }^{\mathrm{b}}$ & & not used & not used & not used \\
\hline in contaminated zone soil ${ }^{\mathrm{b}}$ & & not used & not used & not used \\
\hline Emanating power of radon- $222^{b}$ & - & not used & not used & not used \\
\hline Emanating power of radon $-220^{\mathrm{b}}$ & $\cdot$ & not used & not used & not used \\
\hline Radon vertical dimension of mixing ${ }^{b}$ & $\mathrm{~m}$ & not used & not used & not used \\
\hline Average annual wind speed ${ }^{b}$ & $\mathrm{~m} / \mathrm{s}$ & not used & not used & not used \\
\hline Average building air exchange rate & $1 / \mathrm{h}$ & not used & not used & not used \\
\hline Height of building (room) ${ }^{b}$ & m & not used & not used & not used \\
\hline Building indoor area factor ${ }^{b}$ & - & not used & not used & not used \\
\hline Bulk density of house or building foundation ${ }^{b}$ & $\mathrm{~g} / \mathrm{cm}^{3}$ & not used & not used & not used \\
\hline Thickness of house or building foundation ${ }^{b}$ & $\mathrm{~m}$ & not used & not used & not used \\
\hline Building depth below ground surface & $\mathrm{m}$ & not used & not used & not used \\
\hline
\end{tabular}


TABLE A.1 (Cont'd)

\begin{tabular}{lccccc}
\hline & & & \multicolumn{2}{c}{ Value } \\
\cline { 3 - 5 } & Parameter & Unit & Scenario A & Scenario B & Scenario C \\
\hline Fraction of time spent indsors $^{\mathrm{a}}$ & - & 0.057 & 0.0 & 0.5 \\
Fraction of time spent outdoors & - & 0.171 & 0.086 & 0.25 \\
\hline
\end{tabular}

Values based on site specifications or scenarios assumptions.

b RESRAD default values. 

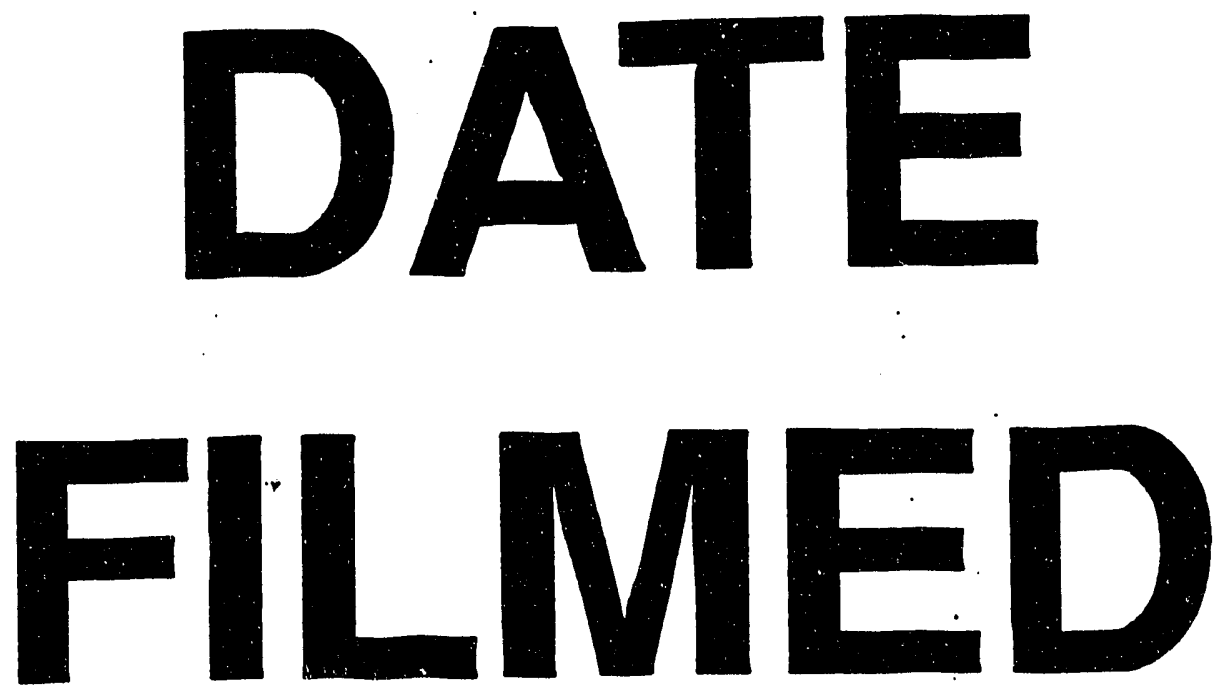

II
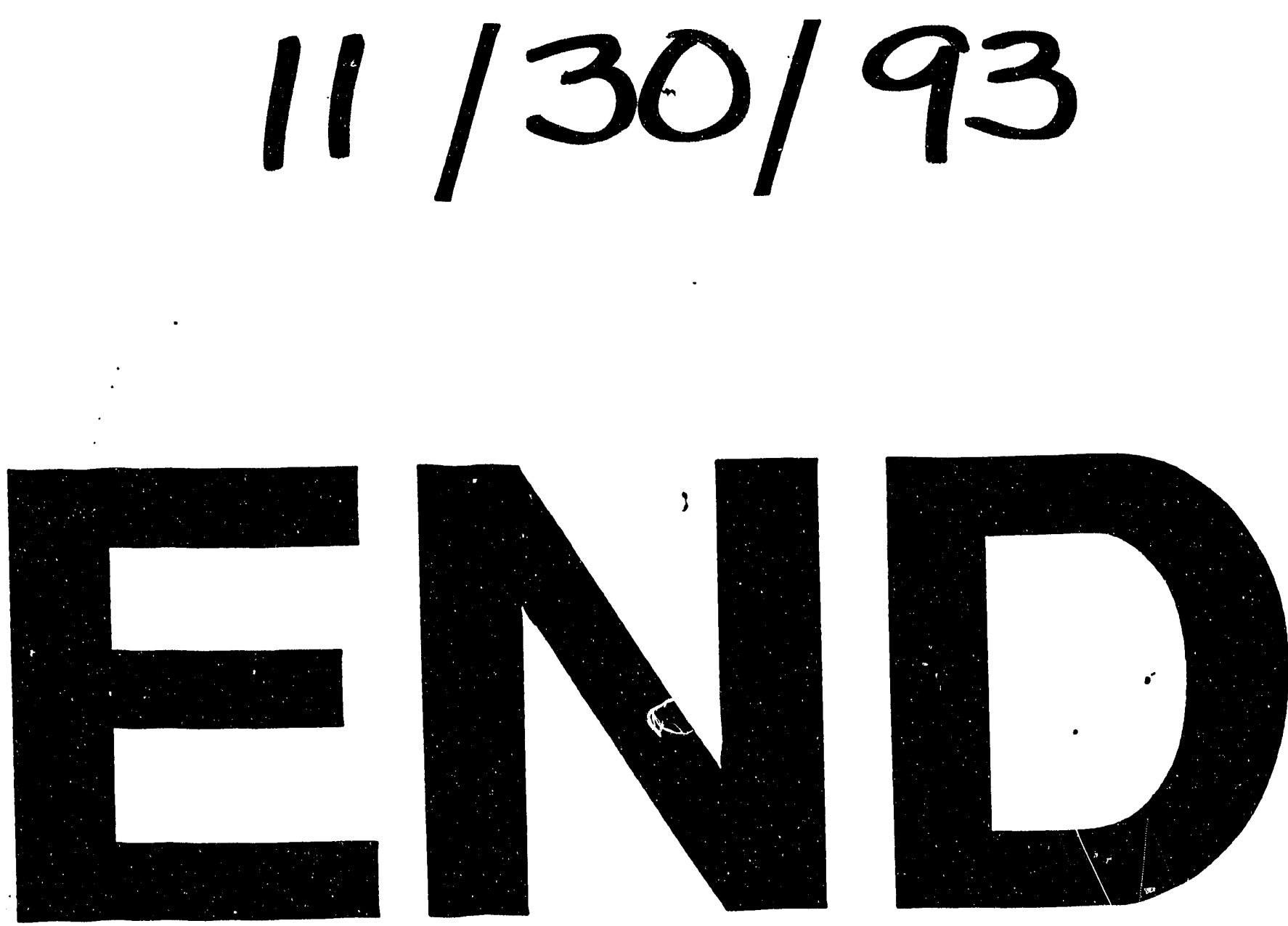


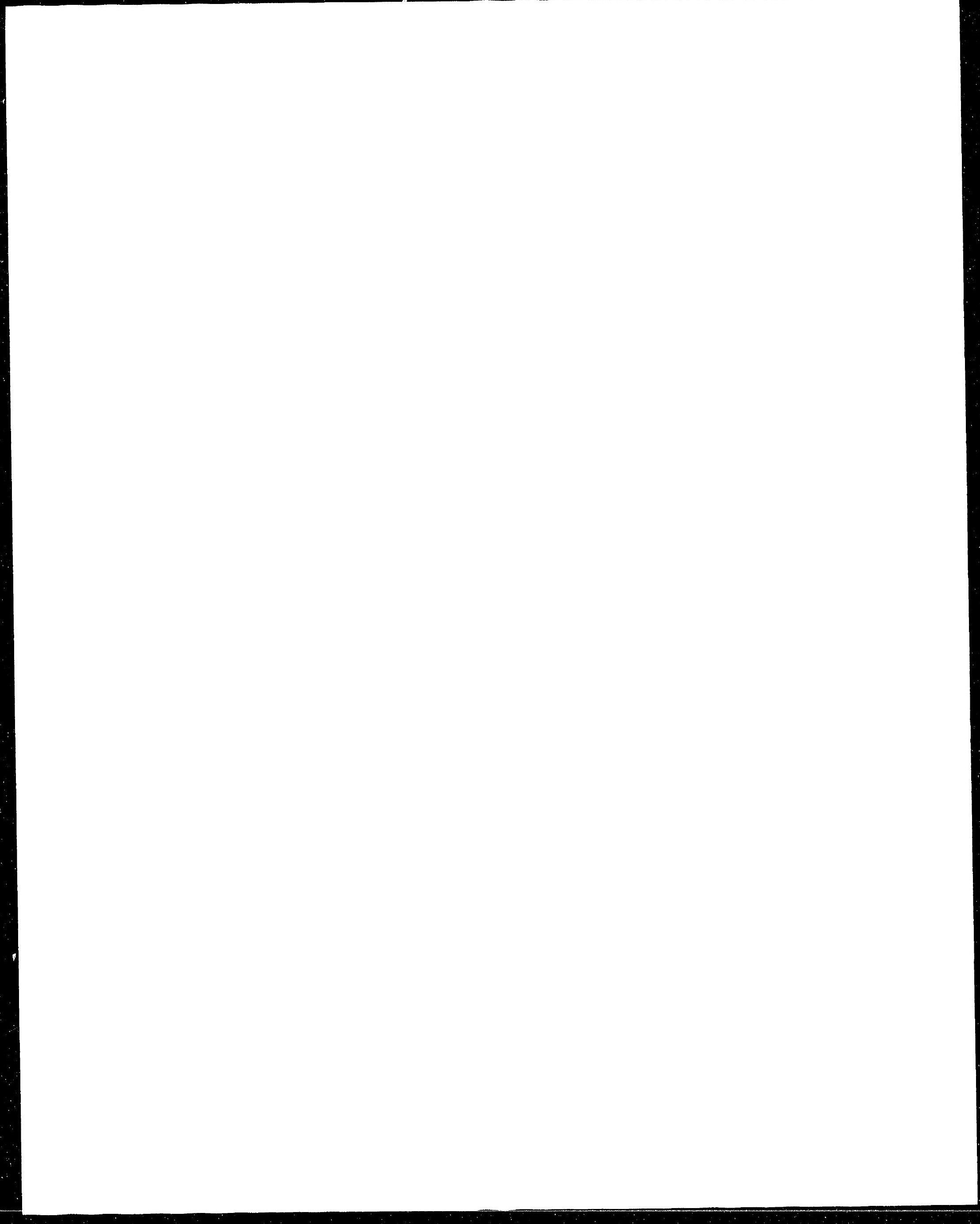

